\title{
RELATIONS BETWEEN INFRASTRUCTURE INNOVATIONS AND TOURISM SPENDING IN DEVELOPED COUNTRIES: A MACROECONOMIC PERSPECTIVE
}

\author{
Beata GAVUROVA (D) ${ }^{*}$, Jaroslav BELAS (iD) ${ }^{2}$, Katarina VALASKOVA (iD) ${ }^{3}$, \\ Martin RIGELSKY (D) 4 , Viera IVANKOVA (D) 5 \\ ${ }^{1,2}$ Faculty of Management and Economics, Tomas Bata University in Zlín, \\ Mostní 5139, 76000 Zlín, Czech Republic \\ ${ }^{3}$ Faculty of Operation and Economics of Transport and Communications, \\ University of Zilina, Univezitna 1, 01026 Zilina, Slovakia \\ ${ }^{4,5}$ Faculty of Management, University of Prešov in Prešov, \\ Konštantínova 16, 08001 Prešov, Slovakia \\ ${ }^{5}$ Faculty of Mining, Ecology, Process Control and Geotechnologies, \\ Technical University of Košice, Letná 9, 04200 Košice, Slovakia
}

Received 27 March 2021; accepted 08 May 2021

\begin{abstract}
Tourism spending as well as innovations are characterized by great economic value, which emphasizes the need for their research from a macroeconomic perspective. The objective of the research was to assess the significance of the relations between infrastructure innovations and tourism spending in a sample of developed countries. The analytical processes included macroeconomic indicators expressing tourism spending and innovations. The research sample consisted of 36 countries of the Organization for Economic Co-operation and Development (OECD) (2010-2019). The analytical processes were primarily performed using robust panel regression and cluster analysis. One of the most important findings is that innovations in information and communication technologies (ICTs) were dominant in terms of the effects on tourism visitors' spending. The results showed that innovations in other areas of infrastructure (general infrastructure, ecological sustainability) should not be neglected either. The significant effects of selected innovation indicators showed positive trajectories. As a result, with the strengthening of innovation activities, an increase in tourism spending is expected, which may lead to economic development. It can be assumed that innovation efforts in countries such as Mexico, the Slovak Republic and Turkey could have great potential for improvement. Based on the results, innovations should be considered a part of tourism development strategies, while ICTs play an important role in this issue. It is desirable to support effective tools to increase the number of innovations in tourism. These innovation efforts at the national level may translate into higher tourism spending, which appears to be economically beneficial.
\end{abstract}

Keywords: economic development, expenditure, innovations, information and communication technologies, infrastructure, ecological sustainability, tourism, OECD.

JEL Classification: O00, O10, O11, Z30, Z32.

${ }^{\star}$ Corresponding author. E-mail: gavurova@utb.cz

Copyright (C) 2021 The Author(s). Published by Vilnius Gediminas Technical University

This is an Open Access article distributed under the terms of the Creative Commons Attribution License (http://creativecommons. $\mathrm{org} / \mathrm{licenses} / \mathrm{by} / 4.0 /$ ), which permits unrestricted use, distribution, and reproduction in any medium, provided the original author and source are credited. 


\section{Introduction}

Innovation is a fundamental pillar in improving living standards and can affect individuals, institutions, entire industries, economic sectors and countries in different ways (OECD \& Eurostat, 2019). Thus, innovations are extremely important for countries' economies, not only at the international level (European Union [EU], Lisbon Strategy, 2020), but also at the regional level, and their importance is growing with increasing public investment in research, education and support for innovation sectors. The tourism sector, which provides services requiring a certain level of innovative knowledge or skills, is no exception. The changing dynamics of society put pressure on innovations in tourism and its adaptation to new business models (Tarí et al., 2020). Innovations disrupt established patterns and tourism is gradually moving away from the mass form that was typical of the 20th century. The position of supply, which greatly affected the mass tourism market, was replaced by unstable demand, as the market was saturated with an increase in the number of destinations. This provides an opportunity to develop innovative and creative thinking that supports the emergence of attractive tourism destinations and services. Lifestyle change also affects the behaviour of tourism visitors; therefore, tourism enterprises are looking for ways to meet the needs of an aging, healthier and wealthier population, which is not looking for the lowest available price, but the best quality at the best price. At the same time, implementing innovation in the tourism sector is a challenge especially for small and medium-sized enterprises (SMEs), which are facing efforts to increase productivity, economies of scale and to improve market position. In particular, innovations in information technology offer new opportunities, which has led to changes in the nature of this sector with environmental, socio-cultural, psychological and economic importance (Gossling, 2017). These aspects have a significant impact on traditional tourism business models. In this sense, today's modern innovations have become a crucial tool for tourism visitors on their trip, and tourism enterprises strive to implement innovations in their business (Amaro et al., 2016; Xiang et al., 2015). All these facts lead to the assumption that innovations in selected areas of infrastructure can also be reflected in the spending of tourism visitors, which plays an important role in tourism characterized as a driving force of economic growth (Lee \& Chang, 2008).

The tourism sector is considered to be very proactive, as evidenced by the development in the field of information and communication technologies (ICTs), networks, databases, electronic marketing and others. The whole marketing process of the tourism sector is significantly changing in order to realize the huge potential of ICTs. This also places increased demands on policy instruments that support innovations without significantly disrupting with market dynamics. In this context, the role of the government in market regulation processes in the tourism sector remains questionable. In any case, governments should support the development of innovative enterprises, while cooperation, technologies or better use of human capital are significant determinants of service innovations (Divisekera \& Nguyen, 2018). Small enterprises are very sensitive to competition, which can be an obstacle to their mutual and beneficial cooperation. According to several international reports, cooperation between SMEs in tourism is insufficient (European Commission, 2014, 2016, 2019). Therefore, in supporting the development of SMEs, governments should explicitly support inno- 
vative tourism policies in order to achieve synergetic effects of innovations and ensure the sustainability of tourism. The sustainability of tourism is closely linked to environmental sustainability (Adedoyin \& Bekun, 2020), and the implementation of eco-innovations can be considered as a differentiating element and a decisive factor for competitiveness in this sector (Alonso-Almeida et al., 2016). It is the governments of countries that can significantly support environmental sustainability. Topics related to environmental protection and sustainability will be an increasingly important criterion in the development of regulatory mechanisms and public policies.

Based on these facts, the issue of innovations and tourism should not be overlooked, as both elements have great economic value. Given the fast-growing sector and technological advances, it is necessary to examine this issue not only at the microeconomic level but also at the macroeconomic level (Buhalis et al., 2019). This was the motivation of this study, which aimed to assess the significance of the relations between innovations in selected areas of infrastructure and tourism spending in a sample of developed countries from a macroeconomic point of view. Thus, the presented research enriches knowledge in the area of innovations in the tourism sector, and the findings provide valuable information for policy makers and other actors in the tourism sector, as well as for regional strategic and development plan makers.

\section{Theoretical background}

Tourism is a very important part of the economy (Dogru \& Bulut, 2018; Li et al., 2018; Uslu et al., 2020). This is evidenced by the fact that tourism in the countries of Organisation for Economic Co-operation and Development (OECD) contributed to gross domestic product (GDP) by an average of $8.8 \%$ in 2019 , with a growing trend since 2016 (World Travel \& Tourism Council [WTTC], 2020) and it significantly reflects the national competitiveness (Ginevicius et al., 2020). For this reason, attention should be paid to those aspects that contribute to the development of tourism, while innovations seem to be of great value. In this context, Popescu (2018) emphasized the fact that the development of sustainable tourism in the future will depend, among other aspects, on innovations. Another important factor in the tourism sector is better general infrastructure (Usmani et al., 2021). Therefore, it can be stated that countries need to grow in terms of innovations in infrastructure that supports the tourism sector. Last but not least, environmental aspects need to be taken into account when addressing tourism development, with sustainable tourism practices and eco-innovations playing an important role (Adedoyin \& Bekun, 2020; Dogru et al., 2020; Kocak et al., 2020).

For these reasons, there is a growing interest in understanding this issue from various perspectives, while the research community focuses mainly on critical and systematic review (Gomezelj, 2016; Pikkemaat et al., 2019; Trunfio \& Campana, 2019) or on examining the implementation of innovations in this sector at local, regional, national or destination level (Gajdosik et al., 2017; Hardy \& Aryal, 2020; Hjalager \& Flagestad, 2012; Makkonen \& Hokkanen, 2013). Another important issue is use of the sharing economy principles in tourism, as described in the research of Fialova and Vasenska (2020) or Krylov (2019). A very interesting idea in the tourism sector could be the idea of democratizing innovations by empowering 
customers to take an active part in co-creation activities, which could be reflected in their stronger behaviour and tourism spending, with the Internet playing an important role in this process (Fuchs \& Schreier, 2011; Grissemann \& Stokburger-Sauer, 2012). In this sense, Buonincontri et al. (2017) used the statistical method of path analysis and they also found a positive relationship between experience co-creation and the satisfaction of tourism visitors and their level of spending. As can be seen, innovations in tourism can be used for various purposes supporting the sector.

In any case, technology readiness and ICT infrastructure are the drivers that are very important for the tourism sector (Racherla et al., 2008; Oliveira \& Martins, 2010). Today's smart innovations enable to capture the movement of tourism visitors in time and space. In this way, it is possible to identify and adapt to their behaviour, which makes it easier for tourism enterprises to offer their services (Gretzel et al., 2015). These modern innovations create a smart socio-technical system that is causing substantial change in travel and tourism (Wang \& Xiang, 2012); therefore, it is necessary to convert all tourism resources to smart tourism resources (Sigala, 2018). It is well known that innovations provide great value for the development and quality of tourism and it can be expected that the development and implementation of innovations may support tourism in terms of improving its potential and opportunities, which may attract more tourism visitors who are willing to spend money in this sector. For this reason, the issue needs to be addressed not only in terms of tourism enterprises and their innovation efforts, but especially in terms of how innovation efforts affect tourism visitors and their spending.

Based on the facts mentioned in the previous paragraph, infrastructure innovations may contribute to the development of tourism. On the other hand, this raises the question of how infrastructure innovations affect tourism spending. At this point, it is necessary to emphasize the findings revealed by Ballina et al. (2019), who confirmed that a greater perception of the usefulness of ICT infrastructure by tourism visitors increases their satisfaction and spending at the destination. Using the Granger causality test, N. Kumar and R. R. Kumar (2020) also confirmed that ICTs can cause demand in tourism. In this context, Rehman et al. (2020) also used Granger causality estimated and revealed a long-term and short-term association between tourism spending and ICT infrastructure in developed countries. In terms of specific forms of innovation and ICT infrastructure, Neuts et al. (2013) found that virtual tours, as one of the modern e-services in tourism, have a positive and significant effect on the level of spending of tourism visitors. On the other hand, these authors also found a negative and significant effect of e-forums. All these innovations provide travel information, which is very important in the decision-making of tourism visitors. According to Vietze (2011), who used ordinary least squares (OLS) multivariate regression analysis, innovations in information infrastructure (e.g. the Internet) have a significant effect on outbound tourism spending. From a macroeconomic point of view, the findings of Milicevic et al. (2020) should not go unnoticed. These authors examined the ICT Development Index and tourism receipts using a panel regression method and they confirmed the indirect positive effect of ICT use on tourism receipts, with tourist arrivals being the mediating variable (Milicevic et al., 2020). Thus, in their study, tourist arrivals and tourism receipts increased with the increasing use of ICTs. In this regard, innovations can be considered as a competitive advantage in tour- 
ism in countries as well as prices of products and services provided (Dvorsky et al., 2020). Innovations in infrastructure provide great opportunities for developing and strengthening tourism (Adeola \& Evans, 2020).

Building on the previous facts, efforts to increase tourism spending through innovations in selected areas of infrastructure can be considered beneficial, as tourism spending is a key indicator of high economic value (Brida \& Scuderi, 2013; Garcia-Sanchez et al., 2013; Usmani et al., 2021). For this reason, the use of tourism spending is preferred to the use of tourist arrivals, as this indicator captures the consumption of goods and services in tourism and the economic effect (Wang \& Davidson, 2010; Fredman, 2008). Tourism spending depends on tourism participation and vice versa (Wu et al., 2013; Yang et al., 2021), and this fact motivates tourism enterprises to meet the needs of tourism visitors. Uyen (2019) pointed to the fact that the main motives and preferences for traveling and spending money are leisure, business and education, while the author considered them to be the drivers of tourism spending. Business tourism is associated with commercial, governmental or educational purposes and activities in various forms of meetings and events (Dragicevic et al., 2012; Nicula \& Elena, 2014). This type of tourism is less represented among tourism visitors, as evidenced by the lower average number of total trips, nights and spending (Ibanescu et al., 2018). Leisure tourism is associated with pleasurable purposes and many activities focused on relaxation, recreation, adventure, sports participation, knowledge of different cultures and countries, but also art and music (David-Negre et al., 2018; Venkatesh, 2006). In any case, there are many determinants of tourism spending (Brida \& Scuderi, 2013; Marrocu et al., 2015; Park et al., 2020; Stefko et al., 2020), and based on the findings in the previous paragraph, innovations are expected to be one of them.

Based on the above-mentioned findings, it is clear that both infrastructure innovations in tourism and tourism spending are well examined at the micro-level, with an emphasis on tourism enterprises and business. However, the macroeconomic perspective is overlooked and the effects of infrastructure innovations on tourism spending are also unexamined. The importance of research at the macroeconomic level is underlined by the fact that both elements are of great value to the national economy as a whole. Hence, the presented study fills this gap and clarifies how innovations in selected areas of infrastructure affect tourism spending in OECD countries.

\section{Methodology}

\subsection{Research objective and questions}

The knowledge base suggests that innovations play an important role in tourism. The findings mentioned in the previous section reveal the assumption that infrastructure innovations can also support the tourism sector in terms of spending, as innovations help enterprises to better identify the needs of tourism visitors who are willing to spend money. Based on this, the primary objective of the presented research was to assess the significance of the relations between innovations in selected areas of infrastructure and tourism spending in a sample of developed countries. These countries were members of the OECD, while Columbia was excluded due to its short membership. Thus, 36 OECD countries were involved in the research. 
The following research questions were formulated:

- RQ I: Is there an effect of information and communication technology innovations on selected indicators of tourism visitors' spending?

- RQ II: Is there an effect of general infrastructure innovations on selected indicators of tourism visitors' spending?

- RQ III: Is there an effect of ecological sustainability innovations on selected indicators of tourism visitors' spending?

\subsection{Research data}

Innovations in selected areas of infrastructure were obtained from the Global Innovation Index (GII) reports from 2011 to 2020. Information on countries' innovation activity have been provided by Cornell University, INSEAD and WIPO (2020a) since 2007, but earlier published data (2007-2010) in the GII reports were not appropriate for research purposes. The reason is that earlier editions of the GII reports contain a minimum of countries and the methodology of compiling the index was still under the process of development in these years. Therefore, this research includes the GII data published from 2011 (4th edition) and later. At the same time, it should be noted that these data were assigned to the data on tourism spending with regard to a one-year lag, i.e. the indicators of infrastructure innovations from 2011 were assigned to the indicators of tourism spending from 2010.

The data on infrastructure innovations consisted of three indicators: information and communication technologies (ICT), general infrastructure (INF), and ecological sustainability (ECL). Table 1 shows their components. In general, the innovation indicators used in the research are measured by an index in the theoretical range from 0 to 100, while a higher value represents a more positive outcome.

Indicators of tourism visitors' spending (TS) were obtained from the World Travel \& Tourism Council (WTTC, 2020), while the oldest data were from 2010 and the most recent data were from 2019. These indicators included business tourism spending (BTS), leisure tourism spending (LTS), domestic tourism spending (DTS) and visitor exports - foreign spending (VEFS). The WTTC defines them as follows: BTS - tourism spending on business trips of domestic residents and foreign visitors in a country, LTS - tourism spending of domestic residents and foreign visitors on leisure purposes in a country, DTS - tourism spending of domestic residents on business and leisure purposes in a country (multi-use consumer durables are not included due to the fact that they are not purchased only for tourism purposes, this is in line with total expenditure on domestic tourism), VEFS - tourism spending of foreign visitors on business and leisure purposes in a country, including transport spending, but excluding international spending on education (WTTC, 2020).

$$
\mathrm{TS}_{i}=\frac{\frac{\mathrm{TS} x_{i} \times 1,000,000,000}{\text { POPULATION } x_{i}}}{\frac{\operatorname{PPP} g d p_{i}}{100}},
$$


Table 1. Description of infrastructure innovation variables (source: Cornell University, INSEAD \& WIPO, 2020b)

\begin{tabular}{|c|c|}
\hline Variables & Variable description \\
\hline \multirow{14}{*}{ ICT } & ICT access (composite index that weights five ICT indicators (20\% each)): \\
\hline & 1. fixed telephone subscriptions per 100 inhabitants; \\
\hline & 2. mobile cellular telephone subscriptions per 100 inhabitants; \\
\hline & 3. international Internet bandwidth (bit/s) per Internet user; \\
\hline & 4. percentage of households with a computer; \\
\hline & 5. percentage of households with Internet access. \\
\hline & ICT use (composite index that weights three ICT indicators (33\% each)): \\
\hline & 1. percentage of individuals using the Internet; \\
\hline & 2. fixed (wired)-broadband Internet subscriptions per 100 inhabitants; \\
\hline & 3. active mobile-broadband subscriptions per 100 inhabitants. \\
\hline & Government online service: \\
\hline & $\begin{array}{l}\text { The Online Services Index component of the E-Government Development Index is a } \\
\text { composite indicator measuring the use of ICTs by governments in delivering public } \\
\text { services at the national level. }\end{array}$ \\
\hline & Online e-participation: \\
\hline & $\begin{array}{l}\text { The E-Participation Index (EPI) is derived as a supplementary index to the United } \\
\text { Nations E-Government Survey. It extends the dimension of the Survey by focusing } \\
\text { on the government use of online services in providing information to its citizens or } \\
\text { "e-information sharing", interacting with stakeholders or "e-consultation" and engaging } \\
\text { in decision-making processes or "e-decision making". }\end{array}$ \\
\hline \multirow{9}{*}{ INF } & Electricity output: \\
\hline & Electricity output - GWh per mn population \\
\hline & $\begin{array}{l}\text { Logistics performance (A multidimensional assessment of logistics performance, the } \\
\text { Logistics Performance Index): }\end{array}$ \\
\hline & 1. the efficiency of customs and border management clearance; \\
\hline & 2. the quality of trade and transport infrastructure; \\
\hline & 3. the ease of arranging competitively priced shipments; \\
\hline & 4. the competence and quality of logistics services; \\
\hline & 5. the ability to track and trace consignments; \\
\hline & $\begin{array}{l}\text { 6. the frequency with which shipments reach consignees within scheduled or expected } \\
\text { delivery times. }\end{array}$ \\
\hline \multirow{8}{*}{ ECL } & Gross capital formation: \\
\hline & Gross capital formation in \% of GDP. \\
\hline & GDP per unit of energy use: \\
\hline & GDP per unit of energy use (2010 PPP\$ per kg of oil equivalent). \\
\hline & Environmental performance: \\
\hline & $\begin{array}{l}\text { The Environmental Performance Index ranks } 180 \text { countries on } 32 \text { performance indicators } \\
\text { across } 11 \text { issue categories covering environmental health and ecosystem vitality. }\end{array}$ \\
\hline & ISO 14001 environment certificates: \\
\hline & $\begin{array}{l}\text { ISO } 14001 \text { Environmental management systems - Requirements with guidance for use: } \\
\text { Number of certificates issued (per billion PPP\$ GDP). }\end{array}$ \\
\hline
\end{tabular}


The WTTC provides data on tourism spending (TS) in billions of dollars $(1,000,000,000$ USD) per country, and these indicators were converted per capita in the first step of the analytical processing. For this purpose, the population of selected countries was obtained from OECD databases (OECD, 2020). These data were then adjusted (by division) using purchasing power parity, OECD.Stat - Purchasing Power Parities for GDP per capita Current PPPs (index for OECD countries, OECD mean $=1$ ).

\subsection{Analytical processes}

The analyses consisted of regression models within OECD countries $(n=36)$ and within the time interval from 2010 to $2019(\mathrm{~T}=10)$ in all countries. One-way individual pooling model, one-way individual fixed (within) effect model, one-way individual random effect model: Swamy-Arora's transformation (Swamy \& Arora, 1972) were applied. The selection (recommendation of preference) of these models was based on the results of the Breusch-Pagan test, the Wooldridge test (for unobserved individual effects) (Wooldridge, 2010), the Baltagi and Li one-sided LM test (Baltagi \& Li, 1995), the F test for the presence of individual effects (or time effect), the Hausman test for panel models and the Angrist Newey test (Angrist \& Newey, 1991). Estimates of these regression models were performed using robust estimation. The Pooling model was estimated using the heteroscedasticity-consistent covariance matrix estimation method, the Arellano method of estimate (Arellano, 1987) was used in the case of the fixed effect model, while the random effect model was estimated using the White 2 estimator. In each analysed case, the regression models contained one endogenous (dependent) variable and one exogenous (independent) variable, indicating simple panel regression models.

In the first steps of the analyses, a statistical description of the indicators and the links between them was carried out in order to present and specify the variables. Descriptive analysis included the basic statistical measures (arithmetic mean, standard deviation, trimmed mean (5\%), interquartile range, median absolute deviation, minimum, maximum, skewness, kurtosis). Correlation analysis was performed using Spearman's nonparametric coefficient $\rho$, subsequently, regression analysis was applied. The final part of the analytical processing was devoted to the application of cluster analysis performed by the algorithm Partitioning Around Medoids (PAM) and Manhattan distances (Schubert \& Rousseeuw, 2019). The number of clusters was estimated using the silhouette method (Kassambara, 2017).

The programming language R v. 4.0.2 (R Core Team, 2020) was used for this analytical processing in R Studio - RStudio, Inc., Boston, MA, U.S.

\section{Results}

This section is divided into three main parts, the first part is devoted to the application of descriptive analysis followed by correlation analysis and regression analysis representing the core of the research. The last part is devoted to cluster analysis that is an applied part of the research. 
Table 2. Mean values for individual countries

\begin{tabular}{|c|c|c|c|c|c|c|c|}
\hline ID & ICT & INF & ECL & BTS & LTS & DTS & VEFS \\
\hline AUS & 79.590 & 49.910 & 45.650 & 547.344 & 2651.458 & 2550.984 & 647.818 \\
\hline AUT & 71.850 & 46.160 & 49.180 & 579.978 & 3503.430 & 2098.137 & 1985.272 \\
\hline BEL & 65.420 & 45.950 & 41.010 & 429.599 & 1208.417 & 752.535 & 885.480 \\
\hline CAN & 78.210 & 57.160 & $\underline{37.740}$ & 662.110 & 1110.189 & 1382.247 & 390.052 \\
\hline CZE & $\underline{53.610}$ & 42.700 & 57.720 & 274.559 & 1178.538 & 600.240 & 852.858 \\
\hline $\mathrm{DEU}$ & 77.660 & 44.600 & 47.400 & 616.661 & 2944.884 & 3067.307 & 494.238 \\
\hline DNK & 79.130 & 40.970 & 54.770 & 949.994 & 1504.864 & 1381.309 & 1073.549 \\
\hline EST & 75.900 & 41.530 & 55.010 & 667.227 & 2123.440 & 718.954 & 2071.712 \\
\hline FIN & 78.820 & 50.850 & 48.530 & 787.445 & 2050.944 & 2082.332 & 756.053 \\
\hline FRA & 80.730 & 45.050 & 46.840 & 494.489 & 2049.795 & 1703.982 & 840.301 \\
\hline GBR & 88.110 & 38.310 & 57.330 & 909.179 & 1905.993 & 2319.834 & 495.337 \\
\hline GRC & 61.270 & $\underline{25.960}$ & 47.020 & 231.903 & 3356.294 & 1405.748 & 2182.451 \\
\hline HUN & 58.740 & $\underline{32.880}$ & 51.610 & $\underline{136.496}$ & 1220.837 & $\underline{391.914}$ & 965.419 \\
\hline $\mathrm{CHE}$ & 69.770 & 47.600 & 64.120 & 517.456 & 2884.631 & 1938.445 & 1463.642 \\
\hline CHL & 63.500 & 34.360 & 41.030 & 268.642 & 1444.860 & 1393.812 & $\underline{319.691}$ \\
\hline IRL & 66.200 & 39.860 & 56.110 & 610.724 & 1354.304 & $\underline{445.542}$ & 1519.486 \\
\hline ISL & 68.100 & 54.680 & $\underline{34.930}$ & 1833.719 & 7018.315 & 2941.739 & 5910.285 \\
\hline ISR & 75.810 & 38.040 & 44.960 & 330.362 & 1637.957 & 951.530 & 1016.789 \\
\hline ITA & 66.450 & 36.200 & 61.410 & 610.951 & 2487.388 & 2358.973 & 739.367 \\
\hline JPN & 83.280 & 46.170 & 51.070 & 598.448 & 1228.505 & 1616.641 & 210.310 \\
\hline KOR & 90.580 & 51.500 & 40.020 & $\underline{180.414}$ & $\underline{721.938}$ & 491.098 & $\underline{411.254}$ \\
\hline LTU & 65.460 & $\underline{27.600}$ & 55.020 & 251.932 & $\underline{900.142}$ & $\underline{489.907}$ & 662.167 \\
\hline LUX & 75.310 & 40.420 & 47.790 & 186.153 & 3725.333 & 697.658 & 3213.826 \\
\hline LVA & $\underline{58.400}$ & $\underline{32.510}$ & 49.600 & 273.648 & 1359.095 & 689.501 & 943.240 \\
\hline MEX & $\underline{55.570}$ & $\underline{31.000}$ & $\underline{37.070}$ & $\underline{156.942}$ & 2553.490 & 2390.340 & $\underline{320.090}$ \\
\hline NDL & 86.790 & 42.460 & 45.930 & 435.952 & 1254.938 & 880.255 & 810.636 \\
\hline NOR & 78.810 & 67.140 & 48.340 & 583.463 & 1817.938 & 1689.357 & 712.043 \\
\hline NZL & 78.560 & 44.910 & 42.540 & 1065.986 & 4683.470 & 3556.521 & 2192.936 \\
\hline POL & 59.230 & 34.420 & 41.500 & $\underline{179.685}$ & $\underline{484.195}$ & $\underline{213.454}$ & 450.426 \\
\hline POR & 64.300 & 33.030 & 50.170 & 533.558 & 2890.424 & 1205.311 & 2218.675 \\
\hline SPN & 75.040 & 39.980 & 64.820 & 372.285 & 2798.035 & 1414.807 & 1755.511 \\
\hline SVK & $\underline{54.980}$ & 33.340 & 57.260 & 367.057 & $\underline{887.144}$ & 636.976 & 617.225 \\
\hline SVN & 61.880 & 35.920 & 49.850 & 394.689 & 2235.952 & 907.752 & 1722.889 \\
\hline SWE & 80.020 & 56.890 & 57.250 & 906.227 & 1888.788 & 1730.987 & 1064.029 \\
\hline TUR & $\underline{48.770}$ & 34.950 & $\underline{37.850}$ & $\underline{138.509}$ & $\underline{853.281}$ & $\underline{451.375}$ & 540.414 \\
\hline USA & 83.310 & 49.550 & $\underline{36.650}$ & 725.061 & 1653.842 & 1939.125 & 439.779 \\
\hline
\end{tabular}

Note: In each column, the five countries with the lowest mean value are underlined and the five countries with the highest mean value are highlighted in bold. 
Table 2 provides the mean values of the indicators for each country. It is appropriate to focus on which countries acquired the maximum values within the individual indicators and, conversely, which countries acquired the minimum values. Subsequently, all these indicators were examined without classification of countries.

Table 3 shows the statistical characteristics of the indicators. Regarding the indicators of infrastructure innovations, the ICT indicator acquired a remarkable value of the central tendency measures (mean: 71.1), while the INF (mean: 42.1) and ICL (mean: 48.7) indicators clearly showed lower values. With a focus on the indicators of tourism spending, the category of the highest spending was represented by the LTS indicator (mean: 2099.3) and, conversely, the category of the lowest spending was represented by the BTS indicator (mean: 522.5). The skewness and kurtosis characteristics indicated some deviations from the normal distribution. As the presented research was mainly based on panel regression models, it was not necessary to consider it as a problem that could significantly affect the results.

Table 4 shows the results of the correlation analysis using Spearman's $\rho$, while the values of the coefficient $\rho$ are given above the diagonal and the values of $\mathrm{p}$ are given below the diagonal. In general, it can be stated that a significant relationship was confirmed in most cases. When interpreting the relationships, it is appropriate to take into account the fact that these are panel data and the internal structure of the panel was not taken into account in the correlation analysis. The assessment of the properties resulting from the data structure was the aim of the following analytical part.

Table 3. Descriptive analysis

\begin{tabular}{|l|c|c|c|c|c|c|c|c|c|c|}
\hline \multicolumn{1}{|c|}{ Var } & Mean & SD & Med & Trim & IQR & MAD & Min & Max & Ske & Kurt \\
\hline ICT & 71.1 & 14.7 & 73.8 & 72.1 & 22.2 & 16.1 & 29.0 & 94.0 & -0.6 & -0.5 \\
\hline INF & 42.1 & 11.3 & 41.4 & 41.9 & 15.7 & 11.6 & 15.7 & 74.8 & 0.2 & -0.2 \\
\hline ECL & 48.8 & 10.1 & 49.2 & 48.6 & 14.7 & 11.1 & 25.1 & 88.7 & 0.2 & -0.2 \\
\hline BTS & 522.5 & 349.3 & 492.4 & 478.7 & 401.5 & 298.3 & 113.0 & 2599.2 & 2.4 & 10.5 \\
\hline LTS & 2099.3 & 1297.3 & 1824.1 & 1919.6 & 1494.2 & 981.3 & 454.8 & 8863.9 & 2.1 & 7.0 \\
\hline DTS & 1430.2 & 849.9 & 1368.6 & 1353.9 & 1342.3 & 1000.9 & 197.5 & 3851.9 & 0.6 & -0.4 \\
\hline VEFS & 1191.5 & 1117.8 & 838.1 & 993.9 & 1002.3 & 557.9 & 67.0 & 8323.0 & 3.3 & 15.4 \\
\hline
\end{tabular}

Note: Var - variable; Mean - arithmetic mean; SD - standard deviation; Med - median; Trim - trimmed mean 5\%; IQR - interquartile range; MAD - median absolute deviation; Min - minimum; Max - maximum; Ske - skewness; Kurt - kurtosis.

Table 4. Correlation analysis: Spearman's $\rho$

\begin{tabular}{|l|c|c|c|c|c|c|c|}
\hline \multicolumn{1}{|c|}{ Corr $\rho$} & ICT & INF & ECL & BTS & LTS & DTS & VEFS \\
\hline ICT & & 0.490 & 0.108 & 0.440 & 0.148 & 0.323 & -0.031 \\
\hline INF & $<0.001$ & & 0.040 & 0.467 & 0.122 & 0.328 & -0.004 \\
\hline ECL & 0.041 & 0.453 & & 0.134 & 0.081 & -0.050 & 0.257 \\
\hline BTS & $<0.001$ & $<0.001$ & 0.011 & & 0.396 & 0.652 & 0.203 \\
\hline LTS & 0.005 & 0.021 & 0.125 & $<0.001$ & & 0.715 & 0.609 \\
\hline DTS & $<0.001$ & $<0.001$ & -0.342 & $<0.001$ & $<0.001$ & & 0.025 \\
\hline VEFS & 0.560 & -0.943 & $<0.001$ & $<0.001$ & $<0.001$ & 0.639 & \\
\hline
\end{tabular}


Table 5. Tests of assumptions of the panel regression model

\begin{tabular}{|l|c|c|c|c|c|c|c|c|}
\hline \multicolumn{1}{|c|}{ Model } & BP & WUE & BL LM & F CNT & F YER & H F-R & RH & AN \\
\hline ICT $\rightarrow$ BTS & $16,75 \dagger$ & $1.82^{\star}$ & $17.03 \dagger$ & $78.96 \dagger$ & 0.707 & $5.89^{* *}$ & $3.74^{*}$ & 39.69 \\
\hline ICT $\rightarrow$ LTS & $4.73^{* *}$ & $2.16^{* *}$ & $15.9 \dagger$ & $170.37 \dagger$ & 0.074 & 0.045 & 0.08 & 32.07 \\
\hline ICT $\rightarrow$ DTS & $2.97^{*}$ & $3.59 \dagger$ & $13.37 \dagger$ & $604.8 \dagger$ & 1.045 & 1.243 & $3.47^{\star}$ & 69.74 \\
\hline ICT $\rightarrow$ VEFS & $9,17^{* * *}$ & $1.76^{*}$ & $16.98 \dagger$ & $89.93 \dagger$ & 0.599 & 1.454 & 1.86 & 21.18 \\
\hline INF $\rightarrow$ BTS & $69.68 \dagger$ & $2.12^{* *}$ & $17.22 \dagger$ & $65.49 \dagger$ & $2.75^{* * *}$ & $712.489 \dagger$ & $7.94^{* * *}$ & $148.13 \dagger$ \\
\hline INF $\rightarrow$ LTS & $39.44 \dagger$ & $2.31^{* *}$ & $16.41 \dagger$ & $130.9 \dagger$ & 0.591 & 0.634 & 0.54 & $138.99 \dagger$ \\
\hline INF $\rightarrow$ DTS & 0.61 & $3.62 \dagger$ & $14.56 \dagger$ & $454.03 \dagger$ & 1.366 & 2.516 & $6.41^{* *}$ & 71.99 \\
\hline INF $\rightarrow$ VEFS & $74.66 \dagger$ & $1.82^{*}$ & $17.18 \dagger$ & $76.37 \dagger$ & 0.51 & 0.049 & 0.04 & $151.49 \dagger$ \\
\hline ECL $\rightarrow$ BTS & $62.38 \dagger$ & $2.2^{* *}$ & $16.98 \dagger$ & $81.72 \dagger$ & 0.637 & 0.38 & 0.19 & 33.67 \\
\hline ECL $\rightarrow$ LTS & $67.41 \dagger$ & $2.25^{* *}$ & $16.09 \dagger$ & $138.33 \dagger$ & 0.763 & 1.114 & 0.54 & 40.59 \\
\hline ECL $\rightarrow$ DTS & $7.87^{* * *}$ & $3.8 \dagger$ & $14.36 \dagger$ & $502.34 \dagger$ & 0.363 & 0.491 & 0.69 & 54.1 \\
\hline ECL $\rightarrow$ VEFS & $91.784 \dagger$ & $1.77^{*}$ & $16.88 \dagger$ & $79.12 \dagger$ & 0.652 & 0.596 & 0.26 & 39.28 \\
\hline
\end{tabular}

Note: ${ }^{*}$ - p-value $<0.1{ }^{* *}$ - p-value $<0.05$; $^{* *}$ - p-value $<0.01 ; \dagger-$ p-value $<0.001 ; \mathrm{BP}-$ Breusch-Pagan test; WUE - Wooldridge’s test for unobserved individual effects; BL LM - Baltagi-Li one-sided LM test; F CNT - F test for the presence of individual effects within countries; F YER - F test for the presence of individual effects within years; H F-R - Hausman (fixed-random) test; RH - Regression-based Hausman test; AN - Angrist and Newey's test.

Table 5 provides the results of the tests of model specifics, and this output supports a selection of methods, the results of which are shown in Table 6. In the first step, a test evaluating the constant variability of residues was applied, i.e. the Breusch-Pagan test of heteroscedasticity. The output of this test showed the presence of significant heteroscedasticity in most of the analysed cases. The significant heteroscedasticity was not confirmed at a significance level lower than 0.05 in two cases $\left(\mathrm{ICT} \rightarrow \mathrm{DTS}=2.97^{\star}\right.$; INF $\rightarrow$ DTS $=0.61$ ). Serial correlation was evaluated using Wooldridge's unobserved effects test and the Baltagi-Li one-sided LM test, while a significant result can be clearly observed in all of the analysed cases. Based on this, it is possible to speak of a significant serial correlation in all cases. Thus, it was reasonable to prefer a robust estimate of the assumed effects. The F test for countries clearly confirmed the effects in all cases, and therefore a panel model was preferred over a model that does not take into account the effects. The opposite situation is evident in the output of the $\mathrm{F}$ test for years, in which the significance of the effects of years occurred only in one case $\left(\mathrm{INF} \rightarrow \mathrm{BTS}=2.75^{\star * *}\right)$. Due to the low occurrence of time effects, only countries were taken into account in the panel model for model uniformity. The sixth and seventh columns show the outputs of the Hausman test and its robust version, as this test tends to favour the fixed model in the case of heteroscedastic data. However, based on the outputs of these tests, it was possible to recommend a fixed model before a random model only in two cases (INF $\rightarrow$ BTS; INF $\rightarrow$ DTS). In the last column, Angrist and Newey's test of fixed model restriction revealed a significant result in several cases, but also in INF $\rightarrow$ BTS, in which the result of the Hausman test recommended a fixed model. Based on the result of Angrist and Newey's test, a preference for a random model was more appropriate in this case. Overall, the random model preference was recommended as the most appropriate model in all but one case (INF $\rightarrow$ DTS). 
Table 6. Regression analysis outputs

\begin{tabular}{|c|c|c|c|c|}
\hline $\begin{array}{c}\text { Model } \\
\left(\mathrm{R}^{2}\right)\end{array}$ & & Pooling $[S E]^{\text {vcov }}$ & Fixed $[S E]^{\text {arellano }}$ & Random [SE] $]^{\text {white }}$ \\
\hline \multirow{2}{*}{$\begin{array}{l}\mathrm{ICT} \rightarrow \mathrm{BTS} \\
(.12 ; .12, .11)\end{array}$} & $\beta$ & $8.38+[4.70-12.06]$ & \multirow{2}{*}{$3.79^{\star *}[0.57-7.01]$} & $3.91 \dagger[2.78-5.04]$ \\
\hline & $\alpha$ & $-73.32[-313.51-166.87]$ & & $244.56+[113.64-375.48]$ \\
\hline \multirow{2}{*}{$\begin{array}{l}\text { ICT } \rightarrow \text { LTS } \\
(.02 ; .23, .21)\end{array}$} & $\beta$ & $12.80^{*}[-2.09-27.69]$ & \multirow{2}{*}{$15.46 \dagger[6.39-24.53]$} & $15.43 \dagger[12.22-18.63]$ \\
\hline & $\alpha$ & $1189.39^{* *}[108.81-2269.98]$ & & $1002.49 \dagger[833.70-1577.82]$ \\
\hline \multirow{2}{*}{$\begin{array}{l}\mathrm{ICT} \rightarrow \mathrm{DTS} \\
(.10 ; .26, .24)\end{array}$} & $\beta$ & $17.99^{* * *[6.14-29.85]}$ & \multirow{2}{*}{$5.78 \dagger[3.07-8.49]$} & $5.82+[4.70-6.94]$ \\
\hline & $\alpha$ & $151.1[-687.11-989.32]$ & & $1016.44 \dagger[742.18-1290.70]$ \\
\hline \multirow{2}{*}{$\begin{array}{l}\text { ICT } \rightarrow \text { VEFS } \\
(.01 ; .14, .13)\end{array}$} & $\beta$ & $3.19\left[\begin{array}{ll}-7.08 & 13.45]\end{array}\right.$ & \multirow{2}{*}{$13.47^{\star *}[2.70-24.24]$} & $13.24 \dagger[9.53-16.95]$ \\
\hline & $\alpha$ & $964.97^{\star * \star}\left[\begin{array}{lll}242.84 & 1687.11\end{array}\right]$ & & $250.48[-196.26-697.22]$ \\
\hline \multirow{2}{*}{$\begin{array}{l}\text { INF } \rightarrow \text { BTS } \\
(.16 ; .01, .01)\end{array}$} & $\beta$ & $12.56^{* * *}\left[\begin{array}{ll}4.62 & 20.51\end{array}\right]$ & \multirow{2}{*}{$1.40^{\star \star}[0.22-2.58]$} & $1.88^{\star *}[0.44-3.31]$ \\
\hline & $\alpha$ & $-6.14\left[\begin{array}{ll}-292.06 & 279.77\end{array}\right]$ & & $443.57 \dagger[341.88-545.26]$ \\
\hline \multirow{2}{*}{$\begin{array}{l}\text { INF } \rightarrow \text { LTS } \\
(.02 ; .01, .01)\end{array}$} & $\beta$ & $17.33[-16.23-50.89]$ & \multirow{2}{*}{$5.11 \dagger[2.43-7.79]$} & $5.35^{\star * *}[1.31-9.39]$ \\
\hline & $\alpha$ & $1370.15^{\star \star[}[98.51-2641.79]$ & & $1874.22 \dagger[1441.61-2306.83]$ \\
\hline \multirow{2}{*}{$\begin{array}{l}\text { INF } \rightarrow \text { DTS } \\
(.09 ; .01, .01)\end{array}$} & $\beta$ & $22.09^{* * *[7.60-36.58]}$ & \multirow{2}{*}{$1.67^{\star \star}[0.20-3.14]$} & $1.79^{* *[0.18-3.40]}$ \\
\hline & $\alpha$ & $500.97[-143.96-1145.89]$ & & $1354.82 \dagger[1084.26-1625.39]$ \\
\hline \multirow{2}{*}{$\begin{array}{l}\text { INF } \rightarrow \text { VEFS } \\
(.01 ; .01, .01)\end{array}$} & $\beta$ & $7.81[-22.47-38.08]$ & \multirow{2}{*}{$4.84^{\star * *}[1.76-7.93]$} & $4.94^{\star *}[0.50-9.38]$ \\
\hline & $\alpha$ & $863.04[-240.01-1966.09]$ & & $983.70 \dagger[613.12-1354.29]$ \\
\hline \multirow{2}{*}{$\begin{array}{l}\mathrm{ECO} \rightarrow \mathrm{BTS} \\
(.01 ; .02, .02)\end{array}$} & $\beta$ & $-0.15[-10.74-10.45]$ & \multirow{2}{*}{$2.68^{\star}[-0.34-5.70]$} & $2.59^{\star * *}[0.78-4.41]$ \\
\hline & $\alpha$ & $529.64^{*}[-57.98-1117.27]$ & & $395.96 \dagger[242.92-548.99]$ \\
\hline \multirow{2}{*}{$\begin{array}{l}\text { ECO } \rightarrow \text { LTS } \\
(.01 ; .04, .04)\end{array}$} & $\beta$ & $6.57[-46.48-33.33]$ & \multirow{2}{*}{$10.63^{\star *}[1.72-19.53]$} & $10.32 \dagger[4.85-15.80]$ \\
\hline & $\alpha$ & $2419.77^{\star \star}[188.22-4651.32]$ & & $1595.92 \dagger[1077.34-2114.51]$ \\
\hline \multirow{2}{*}{$\begin{array}{l}\mathrm{ECO} \rightarrow \mathrm{DTS} \\
(.01 ; .02, .02)\end{array}$} & $\beta$ & $-6.11[-27.57-15.34]$ & \multirow{2}{*}{$2.81^{\star \star}[0.08-5.54]$} & $2.77^{* * *}[0.74-4.79]$ \\
\hline & $\alpha$ & $1728.2^{* * *}[576.95-2879.49]$ & & $1295.35 \dagger[998.50-1592.21]$ \\
\hline \multirow{2}{*}{$\begin{array}{l}\mathrm{ECO} \rightarrow \mathrm{VEFS} \\
(.01 ; .02, .03)\end{array}$} & $\beta$ & $-0.61^{\star * *}[-35.33-34.11]$ & \multirow{2}{*}{$10.49^{* *}[0.19-20.80]$} & $10.16 \dagger[4.17-16.14]$ \\
\hline & $\alpha$ & $1221.19[-737.62-3180.00]$ & & $696.28^{* * *}[199.37-1193.19]$ \\
\hline
\end{tabular}

Note: ${ }^{\star}$ - p-value $<0.1 ;{ }^{\star *}-$ p-value $<0.05 ;{ }^{* *}$ - p-value $<0.01 ; \dagger-$ p-value $<0.001 ;$ SE - standard error; vcov - Robust estimation; arellano - Arellano estimator; white - White 2 estimator.

Table 6 presents the outputs of the panel regression models, while a fixed model and a random model should be preferred as panel methods. It is clear that the significance of the effects was confirmed in the vast majority of the analysed cases. According to Table 5, the fixed model should be preferred for INF $\rightarrow$ BTS $\left(\beta=1.67^{\star *}\right)$, which showed a significant effect. In the other analysed cases, the random model was recommended and the significance $(\alpha=$ $5 \%)$ was confirmed. In all these cases, the positive $\beta$ coefficients are evident, which can be interpreted as meaning that with an increase in infrastructure innovations, an increase in tourism visitors' spending can also be expected. This fact can be considered positive from an economic point of view. Based on the outputs of the coefficient of determination $\left(\mathrm{R}^{2}\right)$, information and communication technologies (ICT) can be seen as the area of infrastructure innovations, in which the effect of efforts would be greatest.

In the last analytical part of this section, the cluster analysis included the selected indicators of tourism spending and infrastructure innovations of individual OECD countries, 
which were adjusted by the arithmetic mean for all years and, subsequently, standardized from 0 to 1 , with 1 representing a more positive result. Due to the presence of outliers, the PAM algorithm was considered the most appropriate algorithm and it was used for clustering. The silhouette method applied to determine the optimal number of clusters recommended two clusters for infrastructure innovation indicators, four clusters for tourism spending indicators, and two clusters for the link between infrastructure innovations and tourism spending. With regard to this link and its clusters, the inputs consisted of the mean values of the indicators of infrastructure innovations (ICT, INF, ECL) and tourism spending (BTS, DTS, LTS, VEFS) after the above-mentioned standardization, while these inputs were again adjusted by the mean. This process created two new variables, infrastructure innovations mean (INFS) and tourism spending mean (TS), which were included in the cluster analysis.
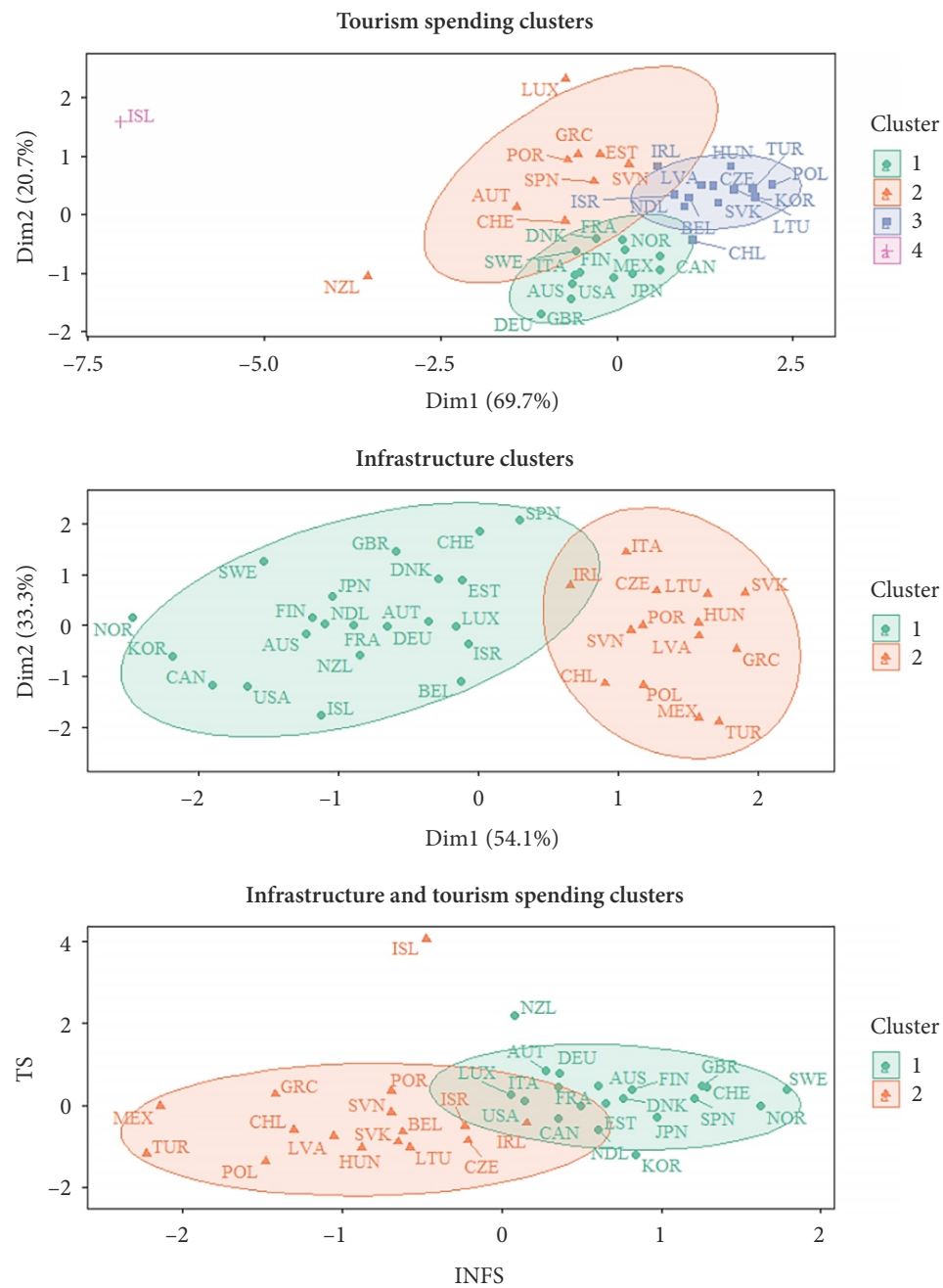

Figure 1. Cluster map for (1) infrastructure innovation indicators; (2) tourism spending indicators; (3) the link between infrastructure innovation and tourism spending indicators 
Figure 1 shows the analysed countries in individual clusters in terms of the dimension of infrastructure innovations, tourism visitors' spending and the link between these indicators (the characteristics linking the mentioned indicators). When interpreting clusters, it is appropriate to take into account the mean values for individual countries, which are given in Table 2. With a focus on the first part of the figure (INFRASTRUCTURE Clusters), the countries in the first cluster can be evaluated more positively than the countries in the second cluster. Based on the output in the second part of the figure (TOURISM SPENDING Clusters), the fourth cluster, which consists of only one country (Iceland), can be considered the most positive, on the other hand, the lowest acquired values were found in the third cluster. The last part of this figure (INFRASTRUCTURE and TOURISM SPENDING Clusters) shows two clusters, and it can be observed that the countries in the second cluster acquired more negative values. Countries represent their position based on the value of TS and INF, and the higher the value, the more positive the result. The second cluster also includes Iceland, which showed very high spending of tourism visitors during the analysed period, but this country lagged behind in terms of infrastructure innovations.

\section{Discussion}

In general, it can be stated that both innovations and tourism are of great economic importance. This fact indicates the importance of research in this issue. Therefore, the objective of this study was to assess the relations between innovations in selected areas of infrastructure and tourism spending in a sample of developed countries. The research revealed interesting findings, which are discussed in this section with many international studies.

The findings from the descriptive analysis indicate that OECD countries achieved a relatively high level of ICTs during the analysed period. This fact is considered to be very positive, as information and communication technologies contribute to economic growth in the short and long term (Kurniawati, 2020), and this encourages investment in infrastructure innovations. Also, ICTs enable participation in co-creation, which is also positively associated with the level of tourism spending (Buonincontri et al., 2017; Fuchs \& Schreier, 2011; Grissemann \& Stokburger-Sauer, 2012). On the other hand, OECD countries achieved remarkably lower levels in areas such as general infrastructure (INF) and ecological sustainability (ECL). In these areas, it was possible to observe results belonging to the lower half of the theoretical range of values. These findings revealed the weakness of the analysed developed countries, as general infrastructure is an important element for tourism development and economic growth (Usmani et al., 2021). Also, the literature emphasizes the role of eco-innovations and green environment in terms of sustainability, while the tourism sector is no exception (Adedoyin \& Bekun, 2020; Dogru et al., 2020; Pikkemaat et al., 2019). Alonso-Almeida et al. (2016) also pointed to the limited development of eco-innovations in tourism and together with our findings, this could motivate countries to proceed a change.

In terms of tourism spending, the highest value was found in the case of leisure tourism spending (LTS), on the contrary, the lowest level was found in the case of business tourism spending (BTS). This result was to be expected, as business tourism is a specific form of tourism that includes specific travel purposes (Dragicevic et al., 2012; Nicula \& Elena, 2014), 
which corresponds to a lower number of total trips, nights and spending compared to leisure purposes (Ibanescu et al., 2018). On the other hand, leisure tourism includes many opportunities to spend money (David-Negre et al., 2018; Venkatesh, 2006). These aspects play an important role in explaining our findings.

With a focus on the mean values of selected indicators within OECD countries, the highest values of the ICT indicator were found in countries such as Korea, the Netherlands and the United Kingdom. Regarding the INF indicator, Norway, Canada and Sweden showed higher mean values among the analysed countries. In the last area of infrastructure innovation, represented by the ECL indicator, higher values could be assigned to countries such as Spain, Switzerland and Italy. From the opposite point of view, Turkey, the Czech Republic and the Slovak Republic showed the lowest mean values of the ICT indicator among the analysed countries. In the case of the INF indicator, the lowest values were found in Greece, Lithuania and Mexico, while countries such as Iceland, the United States and again Mexico showed the lowest mean values in the ECL indicator. In terms of tourism spending represented by the four indicators, countries such as Iceland, New Zealand and Denmark showed the highest values in the BTS indicator, while Iceland, New Zealand and Luxembourg also dominated in the LTS indicator. Similar findings were revealed for the DTS indicator, in which New Zealand, Germany and Iceland had the highest mean values of domestic tourism spending. Regarding the VEFS indicator, the highest values were found in countries such as Iceland, Luxemburg and Portugal. On the other hand, the lowest values of the BTS indicator could be assigned to countries such as Hungary, Turkey and Mexico. In the case of the LTS indicator, Poland, Korea and again Turkey showed the lowest mean values among the analysed countries. Finally, the lowest values in the DTS indicator were shown by Poland, Hungary and Ireland, and countries such as Japan, Chile and Mexico had the lowest values in the VEFS indicator. In general, countries with lower values should be considered as countries with great potential for improvement.

The output of the correlation analysis performed using Spearman's $\rho$ revealed significant relationships in most of the analysed cases. Therefore, it is possible to confirm the relationship between innovations in selected areas of infrastructure and tourism spending. The highest rate of relationship with the ICT indicator was observed for the BTS and DTS indicators, while a moderate to substantial rate was confirmed in both cases. Very similar findings were revealed in the case of relationship with the INF indicator. A moderate to substantial rate of relationship between the ECL indicator and the VEFS indicator was also confirmed. The relationship between innovations in selected areas of infrastructure and tourism spending in developed countries was also confirmed by Rehman et al. (2020), who revealed both long-term and short-term associations. All these facts indicate great opportunities for the development and strengthening of tourism and confirm an important role of innovations in selected areas of infrastructure in this sector (Adeola \& Evans, 2020).

The significance of the effects was examined using robust panel models. Based on several tests, the fixed model and the random model were preferred to the pooling model, and the use of these models can be recommended in statistical procedures of a similar type. After comparing the models, it seems that ignoring the effects could lead to erroneous conclusions. One of the most important findings is the fact that the significant and positive effects of 
innovations in selected areas of infrastructure on tourism spending were confirmed in the vast majority of the analysed cases. Therefore, it can be concluded that with an increase in infrastructure innovations, an increase in tourism visitors' spending can also be expected. Information and communication technologies (ICTs) can be considered as the area of infrastructure innovations with the greatest effect. From a macroeconomic point of view, this is in line with the findings of Vietze (2011), who revealed that this type of information infrastructure has a significant effect on outbound tourism spending. Our finding also agrees with the findings of other studies with a microeconomic perspective, while Ballina et al. (2019) found that a greater perception of the usefulness of ICTs by tourism visitors increases their spending. Subsequently, Neuts et al. (2013) revealed that virtual tours as one of the modern e-services associated with ICT infrastructure in tourism have a positive and significant effect on the level of spending of tourism visitors. In this context, Ardielli (2020) said that participation at the local level is very important as it contributes to the implementation of the concept of Smart Cities.

The output of the cluster analysis revealed the need to pay increased attention to infrastructure innovations in countries such as Mexico, Turkey, Poland, Hungary, the Slovak Republic, but also Lithuania and the Czech Republic. In general, efforts in this area are likely to increase tourism visitors' spending. Special attention should be paid to countries such as Mexico, the Slovak Republic or Turkey, which achieved lower values in the ICT indicator, but also lower tourism spending. This indicates great potential for improvement in these countries. As the results show, these suffering economies are recommended to improve their ICT infrastructure in order to increase tourism spending as well as to develop their tourism (Racherla et al., 2008). At the same time, the development of ICT infrastructure would contribute to their long-term economic growth (Nair et al., 2020).

In terms of innovation potential, the tourism sector faces a major challenge, as there are many areas for improvement. The findings suggest that innovations should be considered a part of tourism development strategies, while ICTs play an important role in the issue. Policy-makers should not overlook these facts, and it is desirable to focus on effective tools and encourage efforts to increase the number of innovations in tourism. The innovation efforts at the national level may translate into higher tourism spending, which appears to be economically beneficial. At present, this issue is even more important, as tourism is severely affected by the coronavirus disease 2019 (COVID-19) pandemic. The COVID-19 pandemic is currently a major challenge for tourism development, while people tend to reduce their spending on tourism during a crisis (Eugenio-Martin \& Campos-Soria, 2014). For this reason, it is necessary to look for effective ways to revitalize tourism, and innovations appear to be one of them. It is appropriate to focus on infrastructure innovations that are attractive to tourism visitors and offer many opportunities to spend money. At a time of travel restrictions, it is appropriate to focus on virtual tourism, in which ICTs play an important role.

The use of ICTs will be a major area for change and innovation in the tourism sector. Building active partnerships and strengthening regional, national and international cooperation is an important recommendation for countries in the context of the results of the analyses. The dynamics of the competitive environment and the processes of globalization create new and more flexible frameworks for cooperation and the need for new models in 
the tourism systems of countries. Innovation in tourism will increasingly depend on networks and cooperation. Therefore, it will be necessary to develop active regional cooperation networks that will have greater potential for the implementation of innovative processes in tourism, as well as for the competitive advantages of countries.

At present, eco-innovation in tourism is gaining attention. It is an approach in which environmental and climate policies are pursued. The level of implementation of eco-innovation varies from country to country, with differences due to several factors, such as resources and support framework. In EU countries, the provision of support for eco-innovation is largely focused on the segment of small and medium-sized enterprises (e.g. Mura, 2020). In the future, this can have a major effect on the transition to environmental sustainability with benefits for innovative enterprises in terms of gaining new customers, entering new markets, attracting new investments and increasing profitability. Eco-innovation does not place such a strong emphasis on the uniqueness of solutions, but the environmental aspect is a key criterion. In addition, enterprises that use eco-innovation have a greater advantage due to ever-tightening regulatory standards. Several studies show that investing in "green" SMEs, which operate in the field of innovative technologies from an environmental point of view, generates above-average profits, creates jobs and mitigates the impact on the environment (OECD, 2013; EU, 2019; Eco-innovation Observatory, 2016). These aspects provide a platform for further research and for the development of international research collaborations that will place emphasis on sustainable tourism and environmental sustainability.

\section{Funding}

This work was supported by Tomas Bata University in Zlín with the project no. FSR-S/2020/ FaME/001.

\section{Conclusions}

The presented research has shown that examining the relations between infrastructure innovations and tourism visitors' spending at the macroeconomic level is beneficial. This issue brings many interesting findings that can be applied in practice in order to increase the economic prosperity of countries as a whole. The objective of the presented research was to assess the significance of the relations between innovations in selected areas of infrastructure and tourism spending in a sample of developed countries. This objective was achieved in three parts of the analytical processes, which consisted of descriptive analysis, regression analysis, and cluster analysis. The main results showed that innovations in selected areas of infrastructure play an important role in the tourism sector, due to the fact that innovation efforts can also be reflected in the development of tourism in terms of expected spending.

In general, it can be concluded that infrastructure innovations have an effect on tourism visitors' spending. One of the most important findings is the fact that ICT infrastructure is an area, in which the effect of innovation efforts would be greatest in terms of tourism spending. The findings also showed that general infrastructure and ecological sustainability should not be neglected either. The positive and significant effects revealed in the research indicate 
that with the strengthening of innovation activities in the analysed infrastructure areas, an increase in tourism spending can be expected. Based on these findings, it was possible to answer all three research questions in the affirmative.

Tourism is often seen as a sector with a lower level of innovations compared to the manufacturing sector, therefore it is necessary to design effective tools to improve this situation, as innovations can significantly support the development of tourism. Based on this, tourism faces a major challenge in fulfilling its innovation potential, and there are many areas for improvement in terms of infrastructure innovations, ICTs and eco-innovations. In particular, the development of ICTs offers many opportunities in this issue, as information and communication technologies make a major contribution to innovation processes. For these reasons, it is strongly recommended that policy makers focus on innovations in their tourism development strategies. Innovation efforts at the national level may translate into higher tourism spending, which appears to be economically beneficial. Accordingly, decision-makers should strongly support ICT infrastructure and implement measures to support general infrastructure with an emphasis on the green environment, while technologies, general innovations and eco-innovations play an important role. At the same time, the attention of policy makers should be focused on improving the education system and supporting science and research in this issue.

Last but not least, policy makers should motivate tourism enterprises and tourism destinations in their innovative behaviour and ensure easy access to innovation processes. Tourism enterprises, as drivers of innovations in this sector, should look at innovation from a strategic point of view. The new opportunities offered by innovations in tourism are a key aspect of achieving a competitive advantage. It is also necessary to take into account the dynamic changes in tourism and in customer preferences, while innovations in ICT infrastructure can help management follow these changes and adapt to them in order to achieve higher profits, as higher tourism spending means higher tourism receipts. In this context, it may be necessary for managers to facilitate the successful implementation of innovative processes, in which traditional tourism resources are transformed into innovative tourism resources.

One of the potential limitations that was identified in the presented research is that the infrastructure innovations have been assessed based on their sub-index, which consist of data of third parties, therefore there is a certain time mismatch in data collection. Another limitation arises from the calculation aspect, meaning that in two models, a significant effect was observed within the analysed years. However, in terms of the composition of the overall structure of the calculations, the effect of years was not taken into account. A potential limitation is also the fact that the results can be generalized only to countries with a higher level of development, as OECD countries were included in the research. The future research activities will be carried out mainly in the field of ICT infrastructure and the sample will include countries with a lower level of development. 


\section{Notations}

Abbreviations
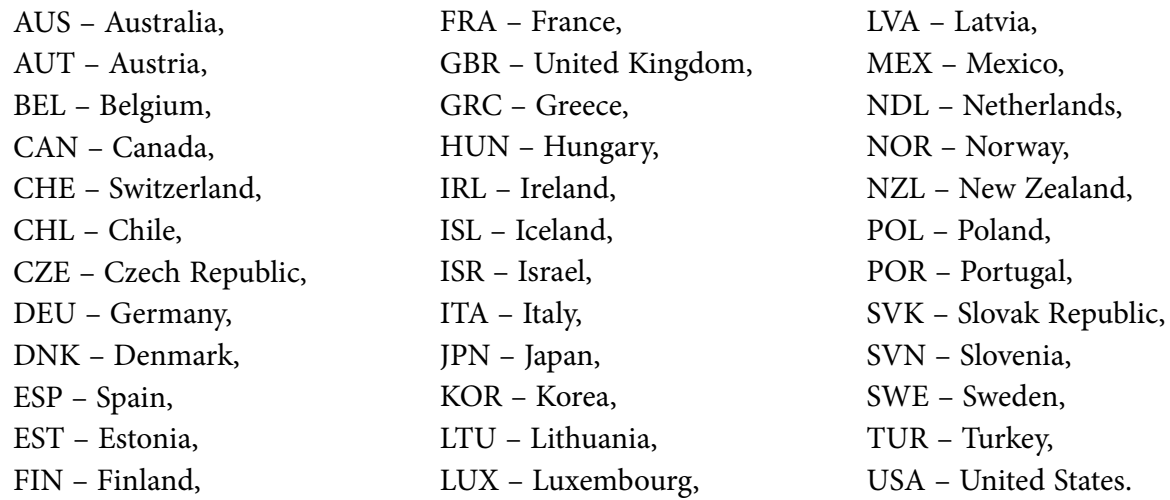

\section{References}

Adedoyin, F. F., \& Bekun, F. V. (2020). Modelling the interaction between tourism, energy consumption, pollutant emissions and urbanization: Renewed evidence from panel VAR. Environmental Science and Pollution Research, 27(31), 38881-38900. https://doi.org/10.1007/s11356-020-09869-9

Adeola, O., \& Evans, O. (2020). ICT, infrastructure, and tourism development in Africa. Tourism Economics, 26(1), 97-114. https://doi.org/10.1177/1354816619827712

Alonso-Almeida, M. D., Rocafort, A., \& Borrajo, F. (2016). Shedding light on eco-innovation in tourism: A critical analysis. Sustainability, 8(12), 1262. https://doi.org/10.3390/su8121262

Amaro, S., Duarte, P., \& Henriques, C. (2016). Travelers' use of social media: A clustering approach. Annals of Tourism Research, 59, 1-15. https://doi.org/10.1016/j.annals.2016.03.007

Angrist, J. D., \& Newey, W. K. (1991). Over-identification tests in earnings functions with fixed effects. Journal of Business and Economic Statistics, 9(3), 317-323. https://doi.org/10.1080/07350015.1991.10509857

Ardielli, E. (2020). Evaluation of eparticipation service's availability on Czech municipal websites. International Journal of Entrepreneurial Knowledge, 8(1), 19-33. https://doi.org/10.37335/ijek.v8i2.99

Arellano, M. (1987). Computing robust standard errors for within-groups estimators. Oxford Bulletin of Economics and Statistics, 49(4), 431-434. https://doi.org/10.1111/j.1468-0084.1987.mp49004006.x

Ballina, F. J., Valdes, L., \& Del Valle, E. (2019). The Phygital experience in the smart tourism destination. International Journal of Tourism Cities, 5(4), 656-671. https://doi.org/10.1108/IJTC-11-2018-0088

Baltagi, B. H., \& Li, Q. (1995). Testing AR (1) against MA(1) disturbances in an error component model. Journal of Econometrics, 68(1), 133-151. https://doi.org/10.1016/0304-4076(94)01646-H

Brida, J. G., \& Scuderi, R. (2013). Determinants of tourist expenditure: a review of microeconometric models. Tourism Management Perspectives, 6, 28-40. https://doi.org/10.1016/j.tmp.2012.10.006

Buhalis, D., Harwood, T., Bogicevic, V., Viglia, G., Beldona, S., \& Hofacker, C. (2019). Technological disruptions in services: Lessons from tourism and hospitality. Journal of Service Management, 30(4), 484-506. https://doi.org/10.1108/JOSM-12-2018-0398

Buonincontri, P., Morvillo, A., Okumus, F., \& Van Niekerk, M. (2017). Managing the experience cocreation process in tourism destinations: Empirical findings from Naples. Tourism Management, 62, 264-277. https://doi.org/10.1016/j.tourman.2017.04.014 
Cornell University, INSEAD, \& WIPO. (2020b). The Global Innovation Index 2020: Who will finance innovation? Cornell University, INSEAD, and the World Intellectual Property Organization, Ithaca, Fontainebleau, and Geneva. https://www.wipo.int/edocs/pubdocs/en/wipo_pub_gii_2020.pdf

Cornell University, INSEAD, \& WIPO. (2020a). About the Global Innovation Index. https://www.globalinnovationindex.org/about-gii\#reports

David-Negre, T., Hernandez, J. M., \& Moreno-Gil, S. (2018). Understanding tourists' leisure expenditure at the destination: A social network analysis. Journal of Travel \& Tourism Marketing, 35(7), 922-937. https://doi.org/10.1080/10548408.2018.1447533

Divisekera, S., \& Nguyen, V. K. (2018). Determinants of innovation in tourism evidence from Australia. Tourism Management, 67, 157-167. https://doi.org/10.1016/j.tourman.2018.01.010

Dogru, T., \& Bulut, U. (2018). Is tourism an engine for economic recovery? Theory and empirical evidence. Tourism Management, 67, 425-434. https://doi.org/10.1016/j.tourman.2017.06.014

Dogru, T., Bulut, U., Kocak, E., Isik, C., Suess, C., \& Sirakaya-Turk, E. (2020). The nexus between tourism, economic growth, renewable energy consumption, and carbon dioxide emissions: Contemporary evidence from OECD countries. Environmental Science and Pollution Research, 27(32), 40930-40948. https://doi.org/10.1007/s11356-020-10110-w

Dragicevic, V., Jovicic, D., Blesic, I., Stankov, U., \& Boskovic, D. (2012). Business tourism destination competitiveness: A case of Vojvodina province (Serbia). Economic Research-Ekonomska Istraživanja, 25(2), 311-331. https://doi.org/10.1080/1331677X.2012.11517510

Dvorsky, J., Kliestik, Z., Cepel, M., \& Strnad, Z. (2020). The influence of some factors of competitiveness on business risks. Journal of Business Economics and Management, 21(5), 1451-1465. https://doi.org/10.3846/jbem.2020.13440

Eco-innovation Observatory. (2016). Eco-innovate: A guide to eco-innovation for SMEs and business coaches. https://cfsd.org.uk/site-pdfs/SME_eco-innovation_guide_2nd_edition_small.pdf

Eugenio-Martin, J. L., \& Campos-Soria, J. A. (2014). Economic crisis and tourism expenditure cutback decision. Annals of Tourism Research, 44, 53-73. https://doi.org/10.1016/j.annals.2013.08.013

European Commission. (2014). Guide on EU funding for the tourism sector (2014-2020). https://ec.europa.eu/growth/content/guide-eu-funding-tourism-sector-2014-2020_en

European Commission. (2016). International tourism trends in EU-28 member states - Current situation and forecast for 2020-2025-2030. European Commission, Directorate General for Enterprise and Industry by the World Tourism Organization (UNWTO). https://ec.europa.eu/growth/content/ international-tourism-trends-eu-28-member-states-current-situation-and-forecast-2020-2025-0_en

European Commission. (2019). Annual report on European SMEs 2018/2019. Research \& Development and Innovation by SMEs. SME Performance Review 2018/2019. https://ec.europa.eu/growth/smes/ sme-strategy/performance-review_en

European Union. (2019). Eco-innovation in Europe. A policy brief from the policy learning platform on environment and resource efficiency. https://euagenda.eu/upload/publications/untitled-202507-ea.pdf

Fialova, V., \& Vasenska, I. (2020). Implications of the COVID-19 crisis for the sharing economy in tourism: The case of Airbnb in the Czech Republic, Ekonomicko-manazerske spektrum, 14(2), 78-89.

Fredman, P. (2008). Determinants of visitor expenditures in mountain tourism. Tourism Economics, 14(2), 297-311. https://doi.org/10.5367/000000008784460418

Fuchs, C., \& Schreier, M. (2011). Customer empowerment in new product development. Journal of Product Innovation Management, 28(1), 17-32. https://doi.org/10.1111/j.1540-5885.2010.00778.x

Gajdosik, T., Gajdosikova, Z., Marakova, V., \& Borsekova, K. (2017). Innovations and networking fostering tourist destination development in Slovakia. Quaestiones Geographicae, 36(4), 103-115. https://doi.org/10.1515/quageo-2017-0039 
Garcia-Sanchez, A., Fernandez-Rubio, E., \& Collado, M. D. (2013). Daily expenses of foreign tourists, length of stay and activities: Evidence from Spain. Tourism Economics, 19(3), 613-630. https://doi.org/10.5367/te.2013.0218

Ginevicius, R., Kliestik, T., Stasiukynas, A., \& Suhajda, K. (2020). The impact of national economic development on the shadow economy. Journal of Competitiveness, 12(3), 39-55. https://doi.org/10.7441/joc.2020.04.03

Gomezelj, D. O. (2016). A systematic review of research on innovation in hospitality and tourism. International Journal of Contemporary Hospitality Management, 28(3), 516-558. https://doi.org/10.1108/IJCHM-10-2014-0510

Gossling, S. (2017). Tourism, information technologies and sustainability: an exploratory review. Journal of Sustainable Tourism, 25(7), 1024-1041. https://doi.org/10.1080/09669582.2015.1122017

Gretzel, U., Sigala, M., Xiang, Z., \& Koo, C. (2015). Smart tourism: foundations and developments. Electronic Markets, 25, 179-188. https://doi.org/10.1007/s12525-015-0196-8

Grissemann, U. S., \& Stokburger-Sauer, N. E. (2012). Customer co-creation of travel services: The role of company support and customer satisfaction with the co-creation performance. Tourism Management, 33(6), 1483-1492. https://doi.org/10.1016/j.tourman.2012.02.002

Hardy, A., \& Aryal, J. (2020). Using innovations to understand tourist mobility in national parks. Journal of Sustainable Tourism, 28(2), 263-283. https://doi.org/10.1080/09669582.2019.1670186

Hjalager, A. M., \& Flagestad, A. (2012). Innovations in well-being tourism in the Nordic countries. Current Issues in Tourism, 16(8), 725-740. https://doi.org/10.1080/13683500.2011.629720

Ibanescu, B. C., Stoleriu, O. M., \& Gheorghiu, A. (2018). Gender differences in tourism behaviour in the European Union. Eastern Journal of European Studies, 9(1), 23-43.

Kassambara, A. (2017). Practical guide to cluster analysis in R: Unsupervised machine learning (Vol. 1, 1 th ed.). STHDA.

Kocak, E., Ulucak, R., \& Ulucak, Z. S. (2020). The impact of tourism developments on $\mathrm{CO}_{2}$ emissions: an advanced panel data estimation. Tourism Management Perspectives, 33, 100611. https://doi.org/10.1016/j.tmp.2019.100611

Krylov, S. (2019). Strategic customer analysis based on balanced scorecard. Ekonomicko-manazerske spektrum, 13(1), 12-25. https://doi.org/10.26552/ems.2019.1.12-25

Kumar, N., \& Kumar, R. R. (2020). Relationship between ICT and international tourism demand: A study of major tourist destinations. Tourism Economics, 26(6), 908-925. https://doi.org/10.1177/1354816619858004

Kurniawati, M. A. (2020). The role of ICT infrastructure, innovation and globalization on economic growth in OECD countries, 1996-2017. Journal of Science and Technology Policy Management, 11(2), 203-225. https://doi.org/10.1108/JSTPM-06-2019-0065

Lee, C. C., \& Chang, C. P. (2008). Tourism development and economic growth: a closer look at panels. Tourism Management, 29(1), 180-192. https://doi.org/10.1016/j.tourman.2007.02.013

Li, K. X., Jin, M., \& Shi, W. (2018). Tourism as an important impetus to promoting economic growth: a critical review. Tourism Management Perspectives, 26, 135-142. https://doi.org/10.1016/j.tmp.2017.10.002

Makkonen, T., \& Hokkanen, T. J. (2013). ICT innovation and local economy: Mobile game as a tourist attraction. Scandinavian Journal of Hospitality and Tourism, 13(3), 257-268. https://doi.org/10.1080/15022250.2013.772770

Marrocu, E., Paci, R., \& Zara, A. (2015). Micro-economic determinants of tourist expenditure: A quantile regression approach. Tourism Management, 50, 13-30.

https://doi.org/10.1016/j.tourman.2015.01.006 
Milicevic, S., Petrovic, J., \& Dordevic, N. (2020). ICT as a factor of destination competitiveness: The case of the republics of former Yugoslavia. Management \& Marketing-Challenges for the Knowledge Society, 15(3), 381-392. https://doi.org/10.2478/mmcks-2020-0022

Mura, L. (2020). Marketing management of family businesses: results of empirical study. International Journal of Entrepreneurial Knowledge, 8(2), 56-66. https://doi.org/10.37335/ijek.v8i2.118

Nair, M., Pradhan, R. P., \& Arvin, M. B. (2020). Endogenous dynamics between R\&D, ICT and economic growth: Empirical evidence from the OECD countries. Technology in Society, 62, 101315. https://doi.org/10.1016/j.techsoc.2020.101315

Neuts, B., Roman, J., Nijkamp, P., \& van Leeuwen, E. (2013). Digital destinations in the tourist sector: A path model for the impact of e-services on tourist expenditures in Amsterdam. Letters in Spatial and Resource Science, 6(2), 71-80. https://doi.org/10.1007/s12076-012-0087-y

Nicula, V., \& Elena, P. R. (2014). Business tourism market developments. Procedia Economics and Finance, 16, 703-712. https://doi.org/10.1016/S2212-5671(14)00858-2

Oliveira, T., \& Martins, M. F. (2010). Understanding e-business adoption across industries in European countries. Industrial Management \& Data Systems, 110(8-9), 1337-1354. https://doi.org/10.1108/02635571011087428

Organisation for Economic Co-operation and Development, \& Eurostat. (2019). Oslo manual 2018: Guidelines for collecting, reporting and using data on innovation. The measurement of scientific, technological and innovation activities (4th ed.). OECD Publishing.

Organisation for Economic Co-operation and Development. (2013). Green innovation in tourism services (OECD Tourism Papers, No. 2013/01). OECD Publishing.

Organisation for Economic Co-operation and Development. (2020). OECD.Stat. https://stats.oecd.org/

Park, S., Woo, M., \& Nicolau, J. L. (2020). Determinant factors of tourist expenses. Journal of Travel Research, 59(2), 267-280. https://doi.org/10.1177/0047287519829257

Pikkemaat, B., Peters, M., \& Bichler, B. F. (2019). Innovation research in tourism: Research streams and actions for the future. Journal of Hospitality and Tourism Management, 41, 184-196.

https://doi.org/10.1016/j.jhtm.2019.10.007

Popescu, A. (2018). Analysis of tourism trends in the new EU member states. In Proceedings of 32nd Conference of the International Business Information Management Association (IBIMA) (pp. 43304346), Seville, Spain.

R Core Team. (2020). R: A language and environment for statistical computing. R Foundation for Statistical Computing, Vienna. https://www.R-project.org/

Racherla, P., Hu, C., \& Hyun, M. Y. (2008). Exploring the role of innovative technologies in building a knowledge-based destination. Current Issues in Tourism, 11(5), 407-428. https://doi.org/10.1080/13683500802316022

Rehman, O. U., Liu, X., Rauf, A., Ben Slama, M., \& Amin, W. (2020). Internet tradition and tourism development: a causality analysis on BRI listed economies. Tourism Economics, 26(6), 926-857. https://doi.org/10.1177/1354816619846251

Schubert, E., \& Rousseeuw, P. J. (2019). Faster $k$-medoids clustering: Improving the PAM, CLARA, and CLARANS algorithms. In G. Amato, C. Gennaro, V. Oria, \& M. Radovanović (Eds.), Lecture notes in computer science: Vol. 11807. Similarity search and applications (pp. 171-187). Springer. https://doi.org/10.1007/978-3-030-32047-8_16

Sigala, M. (2018). New technologies in tourism: from multi-disciplinary to anti-disciplinary advances and trajectories. Tourism Management Perspectives, 25, 151-155.

https://doi.org/10.1016/j.tmp.2017.12.003

Stefko, R., Dzuka, J., Litavcova, E., Nakatova, D., \& Lacny, M. (2020). Psychological characteristics of a tourist as predictors of expenditures: an analytical review and proposal of the predictive model. Contemporary Economics, 14(3), 320-336. https://doi.org/10.5709/ce.1897-9254.407 
Swamy, P. A. V. B., \& Arora, S. S. (1972). The exact finite sample properties of the estimators of coefficients in the error components regression models. Econometrica, 40(2), 261-275. https://doi.org/10.2307/1909405

Tarí, J. J., Pereira-Moliner, J., Molina-Azorín, J. F., \& López-Gamero, M. D. (2020). A taxonomy of quality standard adoption: Its relationship with quality management and performance in tourism organizations in Spain. Journal of Tourism and Services, 21(11), 22-37. https://doi.org/10.29036/jots.v11i21.151

Trunfio, M., \& Campana, S. (2019). Drivers and emerging innovations in knowledge-based destinations: Towards a research agenda. Journal of Destination Marketing \& Management, 14, 100370. https://doi.org/10.1016/j.jdmm.2019.100370

Uslu, A., Alagöz, G., \& Güneş, E. (2020). Socio-cultural, economic, and environmental effects of tourism from the point of view of the local community. Journal of Tourism and Services, 21(11), 1-21. https://doi.org/10.29036/jots.v11i21.147

Usmani, G., Akram, V., \& Praveen, B. (2021). Tourist arrivals, international tourist expenditure, and economic growth in BRIC countries. Journal of Public Affairs, 21(2), e2202. https://doi.org/10.1002/pa.2202

Uyen, J. G. (2019). SEM analysis for tourist expenditure in an emerging country. Economía y Sociedad, 24(56), 68-81. https://doi.org/10.15359/eys.24-56.4

Venkatesh, U. (2006). Leisure: meaning and impact on leisure travel behaviour. Journal of Services Research, 6, 87-108.

Vietze, C. (2011). What's pushing international tourism expenditures? Tourism Economics, 17(2), 237260. https://doi.org/10.5367/te.2011.0039

Wang, D., \& Xiang, Z. (2012). The new landscape of travel: a comprehensive analysis of smartphone apps. In M. Fuchs, F. Ricci, \& L. Cantoni (Eds.), Information and communication technologies in tourism 2012 (pp. 308-319). Springer. https://doi.org/10.1007/978-3-7091-1142-0_27

Wang, Y., \& Davidson, M. C. G. (2010). A review of micro-analyses of tourist expenditure. Current Issues in Tourism, 13(6), 507-524. https://doi.org/10.1080/13683500903406359

Wooldridge, J. M. (2010). Econometric analysis of cross-section and panel data. The MIT Press.

World Travel \& Tourism Council. (2020). Total contribution to GDP. Tourism expenditure. https://wttc.org/

Wu, L., Zhang, J., \& Fujiwara, A. (2013). Tourism participation and expenditure behaviour: analysis using a scobit based discrete-continuous choice model. Annals of Tourism Research, 40, 1-17. https://doi.org/10.1016/j.annals.2012.09.002

Xiang, Z., Tussyadiah, I., \& Buhalis, D. (2015). Smart destinations: foundations, analytics, and applications. Journal of Destination Marketing \& Management, 4(3), 143-144. https://doi.org/10.1016/j.jdmm.2015.07.001

Yang, C.-W., Wu, C.-L., \& Lu, J.-L. (2021). Exploring the interdependency and determinants of tourism participation, expenditure, and duration: an analysis of Taiwanese citizens traveling abroad. Tourism Economics, 27(4), 649-669. https://doi.org/10.1177/1354816619896656 